\title{
Work-life Conflict Factors Influencing the Married Female Nurses: An Empirical Study in Erode District
}

\author{
S. Malathi' and V. Rajeswari ${ }^{2 *}$ \\ 'Ph.d Research Scholar, Bharathiar University, Coimbatore, India \\ ${ }^{2}$ Assistant Professor, Department of Business Administration, Arignar Anna Government Arts College, \\ Namakkal, India; winningstarsraji@gmail.com
}

\begin{abstract}
Working women are challenged by work and family commitments on each day in all the careers. Women working throughout the week are struggling to balance their family and work commitments. When a woman is able to manage her personal and professional life she becomes more committed to her office work. As a result, she is able to achieve success in her career. Further, it will also help her in leading a healthy and peaceful life. Nurses play the major role in health care and thus it is necessary that their needs have to be taken care and a congenial atmosphere is to be created to work with utmost satisfaction. Therefore, the concept of Work-Life Balance along with its implications is a core issue that must be investigated. Married Female nurses struggle with highly demanding familial, personal and societal duties to be performed in their day-to-day life. Any imbalance in their life causes job and family stress leading to health related problems. In order to understand the worklife balance challenges and the various conflict factors influencing the work-life balance, the present study has been proposed to be undertaken. A sample of 200 married female nurses working in Private and Government Hospitals in Erode District were selected and a structured questionnaire was used to collect the information from the respondents. A factorial model has been applied to identify the major work-life conflict factors by KMO Bartlett's Validity test and the Correlation Matrix. The Principal Component Analysis method was also applied to extract the major factors by Varimax rotation. The variables identified are the vital factors which can be concentrated on more by the female nurses in order to avoid work-life conflicts to ensure a balanced life.
\end{abstract}

Keywords: Conflict, Commitment, Psychological Well-being, Work-life Balance

\section{Introduction}

Working women always have to discharge multiple duties, for they need to balance their work and life. According to Aryasri [1] more than $53 \%$ of the working women strive to maintain work-life balance. In the service sector like health care industry, where nurses play a major role in health care are known for rendering regular night duties too. In fact, the role of nurses has grown multifarious from being mere health care takers to health educator, assisting in the diagnostic activities and so on. All these result in both mental and physical work pressure among them. In this backdrop, the concept of work-life balance has been investigated among married female nurses in the Indian context.

\section{Work-Life Balance}

Beauregard [2] defined work-life balance as "satisfaction and good functioning at work and at home, with a minimum of role conflict". Lambert [3] defined burnout as a "syndrome where the worker experiences emotional exhaustion, depersonalization, and a reduced sense of personal accomplishment". The feeling of helplessness to manage the conflict between work and family obligations

${ }^{*}$ Author for correspondence 
is the main source of occupational stress and also ends in occupational and personal dissatisfaction. So the issue of work-life balance among female nurses especially, married need to be recognized as these people are vitally important to the society.

\section{Review of Literature}

Mirzaee S, Zamanian Z, Hasan Zadej [4] probed the impact of work shifts and mental workload on chronic fatigue among female nurses in intensive care units. Kilpatrick and Lavoie-Tremblay [5] asserted that the job related stress was higher in nurses working in rotating shift patterns than nurses who work in fixed shifts. Ezzedeen and Ritchey [6] explored coping strategies adopted by executive women in family relationships to maintain career-family balance. Faisal Hanif1 \& Raza Naqvi [7] confirmed that the workfamily conflicts are negative and significantly related to employee job satisfaction, performance and psychological wellbeing. Dilek and Zeynep [8] examined the extent to which work overload, irregular work schedules, long hours of work and overtime work of nurses were related to their work-family conflicts and satisfaction.

According to Udea [9] when a woman is capable of managing her personal and professional life, then only she can devote to her office work. Yadhav [10] confirmed that work-life balance remains a major issue for employed women in hospitals. Tarannum, Kiran [11] found a better job satisfaction among nurses of government sector in comparison to nurses belonging to private sector. In these circumstances, it is the responsibility of especially the married nurses to identify the factors which bring work-life conflicts, so that they can schedule their activities in such a way to balance their family and professional life and hence the present study has been undertaken in Erode District.

\section{Objectives}

The present study is undertaken with the following objective:

- To identify the major factors that brings work-life conflict among the married female nurses.

\section{Methodology}

\subsection{Data Source and Sampling Design}

The present study is based on primary data obtained from 200 married female nurses selected from various six taluks of Erode District by adopting a convenience random sampling method. The sample comprises 125 married women nurses working in private hospitals and 75 married women nurses working in government hospitals. A well structured questionnaire is used to collect the information from the respondents in the study area. A factorial model has been applied to identify the major work-life conflict factors by KMO Bartlett's Validity test and the Correlation Matrix. The Principal Component Analysis method has also been applied to extract the major factors by Varimax rotation. The variables identified are the vital factors which can be concentrated on more by the female nurses in order to avoid work-life conflicts and ensure balanced life.

\subsection{Analysis of Work-life Conflict Factors through Factor analysis}

Lambert et al. [12] stated that to identify the work-life conflict factors, an exploratory research on the major work conflict factors would help the women in reducing their stress and also balance their family and work life. Hence, for the present study, the opinion of the female nurses in the Erode District was collected with the help of a questionnaire by including various statements with a five point scale (Strongly Agree SA, Agree A, Neutral N, Disagree DA, Strongly Disagree SD) as given in Annexure I.

\section{Analysis and Interpretation}

The collected data is tabulated and analysed by using a Multi-Variate Statistical technique, Exploratory Factor Analysis and the major factors are identified and the entire results are shown in Tables 1 to 3. Brett Williams et al. [13] confirmed the five step Exploratory Factor Analysis (EFA) protocol for pursuing relevant research.

Table 1 shows the Bartlett's test of Sphericity and KAISER MEYER OLKIN measure of sample adequacy which were used to test the appropriateness of the factor model. The KMO index ranging from 0 to 1 , with however, not less than 0.50 validates the employment of factor analysis $[13,14,15]$. Therefore, the value of KMO statistics (.529) was large and affirms the appropriateness of the technique for analyzing the correlation matrix. As the

Table 1. KMO \& Bartlett's test of sphericity

\begin{tabular}{lcc}
\hline $\begin{array}{l}\text { Kaiser-Meyer-Olkin Measure of Sampling } \\
\text { Adequacy. }\end{array}$ & .529 \\
$\begin{array}{l}\text { Bartlett's Test of } \\
\text { Sphericity }\end{array}$ & Approx. Chi-Square & $2.607 \mathrm{E} 3$ \\
& & \\
& Df & 105 \\
& Sig. & .000 \\
\hline Data Source: Primary Data & &
\end{tabular}


correlation between the variables are satisfactory, the results are further derived from the diagramatic representation of Scree Plot and the subsequent tables (Figure 1).

From Table 2, it can be observed that the labelled "initial Eigen values" gives the EIGEN values. The EIGEN value for a factor indicates the 'total variance' variable to the factor. From the extraction sum of squared loadings, it can be learnt that the I factor accounted for a Initial eigen value of 3.757 which was 15 percent; the II factor accounted for the eigen value of 1.877 which was 14.526 percent; the III fac-

\section{Screen Plot}

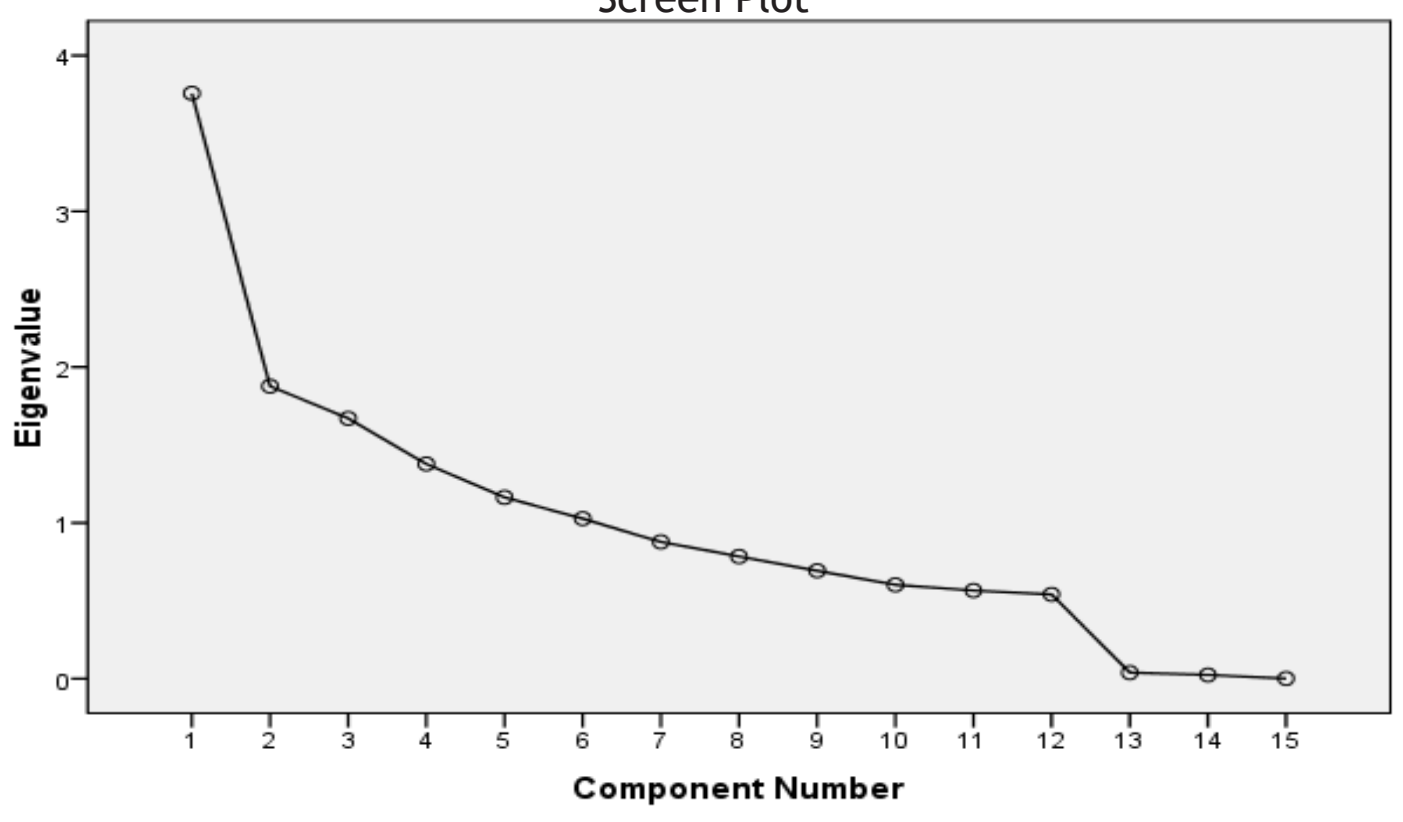

Figure 1. The Scree plot shows Eigen Values on $\mathrm{Y}$ axis and Components on $\mathrm{X}$ axis and the components which are with eigen values above 1 are considered as the extracted factors.

Table 2. Total variance explained

\begin{tabular}{|c|c|c|c|c|c|c|c|c|c|}
\hline \multirow[t]{2}{*}{$\begin{array}{l}\text { Component } \\
\text { No }\end{array}$} & \multicolumn{3}{|c|}{ Initial Eigen values } & \multicolumn{3}{|c|}{$\begin{array}{c}\text { Extraction Sums of Squared } \\
\text { Loadings }\end{array}$} & \multicolumn{3}{|c|}{ Rotation Sums of Squared Loadings } \\
\hline & Total & $\begin{array}{c}\% \text { of } \\
\text { Variance }\end{array}$ & $\begin{array}{c}\text { Cumulative } \\
\%\end{array}$ & Total & $\begin{array}{c}\% \text { of } \\
\text { Variance }\end{array}$ & $\begin{array}{c}\text { Cumulative } \\
\%\end{array}$ & Total & $\begin{array}{c}\% \text { of } \\
\text { Variance }\end{array}$ & $\begin{array}{c}\text { Cumulative } \\
\%\end{array}$ \\
\hline 1 & 3.757 & 25.048 & 25.048 & 3.757 & 25.048 & 25.048 & 2.278 & 15.190 & 15.190 \\
\hline 2 & 1.877 & 12.515 & 37.563 & 1.877 & 12.515 & 37.563 & 2.179 & 14.526 & 29.716 \\
\hline 3 & 1.671 & 11.139 & 48.703 & 1.671 & 11.139 & 48.703 & 2.049 & 13.657 & 43.373 \\
\hline 4 & 1.378 & 9.184 & 57.887 & 1.378 & 9.184 & 57.887 & 1.629 & 10.858 & 54.231 \\
\hline 5 & 1.164 & 7.757 & 65.644 & 1.164 & 7.757 & 65.644 & 1.546 & 10.305 & 64.536 \\
\hline 6 & 1.027 & 6.848 & 72.492 & 1.027 & 6.848 & 72.492 & 1.193 & 7.956 & 72.492 \\
\hline 7 & .877 & 5.849 & 78.342 & & & & & & \\
\hline 8 & .784 & 5.227 & 83.569 & & & & & & \\
\hline 9 & .693 & 4.617 & 88.186 & & & & & & \\
\hline 10 & .602 & 4.015 & 92.201 & & & & & & \\
\hline 11 & .566 & 3.772 & 95.973 & & & & & & \\
\hline 12 & .541 & 3.605 & 99.578 & & & & & & \\
\hline 13 & .039 & .258 & 99.836 & & & & & & \\
\hline 14 & .024 & .158 & 99.994 & & & & & & \\
\hline 15 & .001 & .006 & 100.000 & & & & & & \\
\hline
\end{tabular}

Data Source : Primary Data ;

Extraction Method: Principal Component Analysis. 
tor accounted for the eigen value of 1.671 which was 13.657 percent and the IV factor accounted for the variance of 1.378 which was 10.858 percent. Factor V accounted for the initial eigen values of 1.164 which was 10.305 percent; the VI factor accounted for the eigen value of 1.027 which was 7.56 percent with a total cumulative variance of 72.492 percent.

\subsection{Determination of Factors Based on Eigen Values}

In Exploratory Factor Analysis, only factors with Eigen values greater than 1.00 are retained and the interpretation is facilitated by identifying the variables that have large loadings on the same factor. Hence, those factors with high factor loadings in each component i.e. values greater than 0.5 were selected as exhibited in Table 3 .

Based on Table 3, those six factors extracted with the variables of values above. 5 are selected and named separately as shown in Table 4.

It is evident from Table 4 that the variables 7 and 14 were grouped together as factor I which accounted for $15.190 \%$ of the total variance and had been named as Management Attitude and Level of Family Responsibilities. The variables 8 and 15 were grouped as fa ctor II with the total variance of $14.526 \%$ and had been named as Level of Family Life Sacrifice. The variables 6 and 13 were grouped under factor III with the total variance of $13.657 \%$ and had been named as Household Commitments and the variables 4, 5 and 10 were grouped under factor IV with the total variance of $10.858 \%$ and had been named as Capacity to Postpone Family Commitments. The variables 2, 9, and 11 were grouped under factor $\mathrm{V}$ with the total variance of $10.305 \%$ and had been named as Level of Work Pressure and Leave Availability. The variable 1 was grouped under factor VI with the total variance of $7.956 \%$ and had been named as Recognition by the Supervisors.

\section{Findings}

From the analysis, it is evident that out of 15 factors analysed, VI component factors were extracted through the analysis. They were named as Management Attitude and Level of Family Responsibilities, Level of Family Life Sacrifice, Household Commitments, Capacity to Postpone Family Commitments, Level of Work Pressure and Leave Availability, and Recognition of Supervisors respectively.

\section{Suggestions}

Based on the findings, the following suggestions have been made:

i) The management of hospitals can show concern to the nurses in case of emergencies.

Table 3. Rotated component matrix

\begin{tabular}{lcccccc}
\hline & \multicolumn{7}{c}{ Component } \\
\cline { 2 - 7 } & 1 & 2 & 3 & 4 & 5 & 6 \\
\hline VAR00001 & -.012 & -.015 & .032 & -.056 & .048 & .857 \\
VAR00002 & -.120 & .180 & -.009 & .268 & .533 & .310 \\
VAR00003 & .183 & .394 & .255 & .400 & .132 & .143 \\
VAR00004 & .066 & -.069 & .056 & .631 & .411 & -.187 \\
VAR00005 & .239 & .049 & .049 & .637 & .185 & -.183 \\
VAR00006 & .060 & .138 & .969 & .045 & .073 & .032 \\
VAR00007 & .944 & .075 & .024 & .135 & -.015 & -.071 \\
VAR00008 & .109 & .957 & .131 & .052 & .162 & .004 \\
VAR00009 & .312 & .122 & .017 & .034 & .626 & .251 \\
VAR00010 & -.180 & .155 & -.098 & .694 & -.277 & .282 \\
VAR00011 & -.034 & .169 & .157 & .034 & .678 & -.174 \\
VAR00012 & .483 & .173 & .169 & -.262 & .214 & .306 \\
VAR00013 & .055 & .139 & .969 & .004 & .084 & .009 \\
VAR00014 & .941 & .100 & .045 & .106 & .029 & -.041 \\
VAR00015 & .104 & .958 & .128 & .047 & .159 & -.003 \\
\hline Source: Primary Data & & & & & & \\
Extraction Method: Principal Component Analysis. & & & \\
Rotation Method: Varimax with Kaiser Normalization. Rotation converged in 16 iterations.
\end{tabular}


Table 4. Naming of factors extracted

\begin{tabular}{|c|c|c|}
\hline Factor \& \% of Total Variance & Variables & $\begin{array}{l}\text { Rotated factor } \\
\text { loading }\end{array}$ \\
\hline $\begin{array}{l}\text { I (15.190\%) Management } \\
\text { Attitude and Level of Family } \\
\text { Responsibilities }\end{array}$ & $\begin{array}{l}\text { 7. In this hospital, the management does not encourage } \\
\text { leaves availed for family related matters. } \\
\text { 14. My responsibilities at home reduce the effort that I } \\
\text { can devote to job. }\end{array}$ & .944 \\
\hline $\begin{array}{l}\text { II }(14.526 \%) \\
\text { Level of Family Life Sacrifice }\end{array}$ & $\begin{array}{l}\text { 8. I avoid personal needs some times because of my } \\
\text { work. } \\
\text { 15. I cannot be able to work on time due to my family } \\
\text { commitments }\end{array}$ & $\begin{array}{l}.957 \\
.957 \\
.958\end{array}$ \\
\hline $\begin{array}{l}\text { III }(13.657 \%) \\
\text { Household Commitments }\end{array}$ & $\begin{array}{l}\text { 6. I would carry official work to home some times } \\
\text { 13. The household duties prevents me from getting } \\
\text { enough sleep to perform my job well }\end{array}$ & $\begin{array}{l}.969 \\
.969\end{array}$ \\
\hline $\begin{array}{l}\text { IV }(10.858 \%) \\
\text { Capacity to Postpone Personal } \\
\text { Commitments }\end{array}$ & $\begin{array}{l}\text { 4. I put personal life on hold for work. } \\
\text { 5. I would change my personal plans frequently because } \\
\text { of my work pressures } \\
\text { 10. The stress at home reduces my work efficiency }\end{array}$ & $\begin{array}{l}.631 \\
637 \\
.694\end{array}$ \\
\hline $\begin{array}{l}\text { V }(10.305 \%) \\
\text { Level of Work Pressure and Leave } \\
\text { Availability }\end{array}$ & $\begin{array}{l}\text { 2. My job reduces the effort that I provide to } \\
\text { commitments at home. } \\
\text { 9. My personal life suffers because of work pressures. } \\
\text { 11. I need to take plenty of leaves to fulfill my family } \\
\text { needs }\end{array}$ & $\begin{array}{l}.533 \\
.626 \\
.678\end{array}$ \\
\hline $\begin{array}{l}\text { VI }(7.956 \%) \\
\text { Recognition by the Supervisors }\end{array}$ & $\begin{array}{l}\text { 1. To get noticed in my hospital, I need to put work } \\
\text { constantly ahead of my family life. }\end{array}$ & .857 \\
\hline
\end{tabular}

ii) Nurses can plan their family work in advance so that the conflicts of work and family can be avoided.

iii) Leave can be sanctioned to workers on a scheduled basis so that personal commitments can be fulfilled.

\section{Conclusion}

Working women are stressed by work and family commitments on each day especially, nurse. So it is very important for the nurses to identify the major factors which cause the work-life conflict in order to lead a balanced life. This paper highlights the factors which create the conflict among the married female nurses in their work and family life, which if concentrated on would enable them to avoid such issues.

\section{References}

1. Aryasri, A.R. \& Babu, S.S. "Impact of flextime on work-life balance practice on employee retention," NHRD Network Journals, vol. 2(3), pp. 68-75, 2009.

2. Beauregard, T., \& Henry, L.C. "Making the link between work-life balance practices and organizational performance", Human Resource Management Review, vol. 19(1), pp. 9-22, 2009.
3. Lambert, S.J. "Process linking work and family: A critical review and research agenda", Human Relations, vol. 43(3), pp. 239-257, 1990.

4. Mirzaee, S., Zamanian, Z., \& Hasan, Z.J. "Effects of work shifts and mental workload on chronic fatigue among female nurses inintensive care units", Journal of health sci surveillance sys. vol. 3(3), pp. 113-118, 2015.

5. Kilpatrick, K., \& Lavoie-Tremblay, M. "Shiftwork: What health care managers need to know", The Health Care Manager, vol. 25, pp. 160-166, 2006.

6. Ezzedeen, S.R., \& Ritchey, K.G. "Career advancement and family balance strategies of executive women", Gender in Management, vol. 24(6), pp. 388-411, 2009.

7. Hanif1, F., \& Naqvi, S.M.M.R. "Analysis of Work Family Conflict in View of Nurses, in Health Sector of Pakistan", International Journal of Gender and Women's Studies, vol. 2(4), pp. 103-116, 2014.

8. Yildirim, D.A., \& Aycan, Z. "Nurses work demands and work-family conflict: A questionnaire survey", International journal of nursing studies, vol. 45(9), pp. 1366-1378, 2008.

9. Ueda, Y. "The relationship between work-life balance programs and employee satisfaction: Gender differences in the moderating effect of annual income." Journal of Business Administration Research, vol. 1(1), pp. 65-74, 2012.

10. Yadav, R.K., \& Dabhade, N. "Work-life balance amongst the working women in public sector banks-A case study of State 
Bank of India", International Letters of Social and Humanistic Sciences, vol. 7(1), pp. 1-22, 2013.

11. Jahan, T., \& Kiran, U.V. "An evaluation of job satisfaction of nurses across working sector", International journal of humanities and social science invention, vol. 2(6), pp. 37, 2013.

12. Lambert, E.G., Hogan, N.L., \& Altheimer, I. "An exploratory examination of the consequence of burnout in terms of life satisfaction, turnover intent, and absenteeism among private correctional Staff," The Prison Journal, vol. 90(1), pp. 94-114, 2010 .
13. Williams, B., Onsman, A., \& Brown, T. "Exploratory factor analysis: A five-step guide for novices”, Journal of Emergency Primary Health Care (JEPHC), vol. 8(3), Article 990399, pp. $1-13,2010$.

14. Hair, J., Anderson, R.E., Tatham, R.L., \& Black, W.C. Multivariate Data Analysis (4 ${ }^{\text {th }}$ Ed.). New Jersey: Prentice Hall Inc., 1995. p. 373.

15. Tabachnick, B.G., Fidell, L.S. Using Multivariate Statistics. Boston: Pearson Education Inc., 2007. p. 611. 


\section{Annexure I}

Opinion on the Work - Life conflict factors based on your personal experience (5-Strongly agree, 4-Agree, 3-Neutral,2-Disagree,1-Strongly disagree)

\begin{tabular}{|c|c|c|c|c|c|c|}
\hline SNo & Work- life conflict factors & $\begin{array}{l}\text { SA } \\
(5)\end{array}$ & $\begin{array}{c}\text { A } \\
(4)\end{array}$ & $\begin{array}{l}\mathrm{N} \\
(3)\end{array}$ & $\begin{array}{l}\mathrm{DA} \\
(2)\end{array}$ & $\begin{array}{c}\text { SDA } \\
(1)\end{array}$ \\
\hline 1 & $\begin{array}{l}\text { To get noticed in my hospital, I need to put work constantly a head of my } \\
\text { family life. }\end{array}$ & & & & & \\
\hline 2 & My job reduces the effort that I provide to commitments at home. & & & & & \\
\hline 3 & $\begin{array}{l}\text { The good companion at job makes me to perform better and vice versa at } \\
\text { homes }\end{array}$ & & & & & \\
\hline 4 & I put personal life on hold for work. & & & & & \\
\hline 5 & I would change my personal plans frequently because of my work pressures & & & & & \\
\hline 6 & I would carry official work to home some times & & & & & \\
\hline 7 & $\begin{array}{l}\text { In this hospital, the management does not encourage leaves availed for } \\
\text { family related matters. }\end{array}$ & & & & & \\
\hline 8 & I avoid personal needs some times because of my work. & & & & & \\
\hline 9 & My personal life suffers because of work pressures. & & & & & \\
\hline 10 & The stress at home reduces my work efficiency & & & & & \\
\hline 11 & I need to take plenty of leaves to fulfil my family needs. & & & & & \\
\hline 12 & I get distracted at work thinking at home and personal worries. & & & & & \\
\hline 13 & $\begin{array}{l}\text { The household duties prevents me from getting enough sleep to perform } \\
\text { my job well }\end{array}$ & & & & & \\
\hline 14 & My responsibilities at home reduce the effort that I can devote to job. & & & & & \\
\hline 15 & I cannot be able to work on time due to my family commitments & & & & & \\
\hline
\end{tabular}

